\title{
PASK wt Allele
}

National Cancer Institute

\section{Source}

National Cancer Institute. PASK wt Allele. NCI Thesaurus. Code C132044.

Human PASK wild-type allele is located in the vicinity of $2 q 37.3$ and is approximately $44 \mathrm{~kb}$ in length. This allele, which encodes PAS domain-containing serine/threonine-protein kinase protein, plays a role in serine/threonine protein phosphorylation. 